\title{
PEMBELAJARAN MATEMATIKA REALISTIK YANG MELIBATKAN KECERDASAN MAJEMUK PADA MATERI VOLUME BANGUN DAN LUAS PERMUKAAN UNTUK SEKOLAH DASAR
}

\author{
Tri Achmad Budi Susilo, Achmad Dhany Fachrudin, Soffil Widadah, \\ Ahmad Wachidul Kohar \\ Program Studi Pendidikan Matematika, STKIP PGRI SIdoarjo
}

\begin{abstract}
Abstrak
Penelitian ini bertujuan untuk merancang desain pembelajaran matematika realistik yang melibatkan kecerdasan majemuk pada materi volume dan luas permukaan kubus dan balok di kelas V SD. Design research dipiih sebagai jenis penelitian yang terdiri dari preliminary design, pilot experiment dan teaching experiment. Dengan mengintegrasikan tujuh kecerdasan majemuk seperti kecerdasan verbal, kecerdasan visual/spasial, kecerdasan logis/matematis, kecerdasan interpersonal dan intrapersonal, kecerdasan kinestetik, dan kecerdasan musikal pada materi ini, diperoleh desain pembelajaran dengan local instructional theory yang mencakup aktivitas: Pilot experiment dilaksanakan di MI Faqih Hasyim dengan melibatkan 6 siswa kelas V. Kegiatan ini dilaksanakan selama 5 kali pertemuan, dengan rinciam kegiatan sebagai berikut: 1) pretest, 2) menemukan susunan jaring-jaring kubus dan balok melalui aktivitas enggulung model kubus atau balok, 3) menemukan konsep volume melalui aktivitas 'kotak mana yang lebih besar?', 4) menentukan isi kubus berdasarkan gambar tampak depan, belakang, dan samping, 5) membungkus tanah liat untuk menentukan luas permukaan balok, 6) menentukan luas permukaan balok dan kubus berdasarkan jaring-jaringnya, 7) menemukan strategi menentukan volume balok kubus melalui masalah 'nasi kotak', dan 8) menyusun model susunn kubus dan balok dari 'model kubus satuan' dengan berbgai ukuran, namun dengan volume yang tetap. Tahapan selanjutnya dari penelitian ini adalah melaksanakan teaching experiment pada satu kelas (35 siswa) berdasarkan hasil analisis restropektif pada tahap pilot experiment yang telah dilakukan sebelumnya.

Kata Kunci: Kecerdasan majemuk, pembelajaran matematika realistik, lintasan belajar, volume bangun ruang, luas permukaan bangun ruang, desain riset, Sekolah Dasar
\end{abstract}

\begin{abstract}
An abstranct is a brief summary of a research article, thesis, review, conference proceeding or any-depth analysis of a particular subject or disipline, and is often used to help the reader quickly ascertain the paper
\end{abstract}


purposes. When used, an abstract always appears at the beginning of a manuscript or typescript, acting as the point-of-entry for any given academic paper or patent application. Absatrcting and indexing services for various academic discipline are aimed at compiling a body of literature for that particular subject. Abstract length varies by discipline and publisher requirements. Abstracts are typically sectioned logically as an overview of what appears in the paper.

Keywords: content, formatting, article.

\section{PENDAHULUAN}

Teori kecerdasan majemuk yang diungkapkan oleh Gardner $(1983,1999)$ telah menunjukkan banyak manfaat dalam bidang rancangan pembelajaran, tidak terkecuali pembelajaran matematika. Manfaat tersebut diantaranya mampu memfasilitasi siswa dengan berbagai macam jenis kecerdasan (Armstrong, 2000; Kohar \& Rosyidi, 2012), mengurangi kecenderungan guru untuk mengajar dengan metode yang hanya sesuai dengan jenis kecerdasan paling menonjol yang mereka miliki (Sulaiman, Abdurrahman, \& Rahim, 2010), meningkatkan capaian hasil belajar matematika (Işı1k \& Tarım, 2009; Temur, 2007), dan menumbuhkan motivasi belajar matematika siswa (Bednar, 2002). Hasil yang positif ini juga didukung oleh pandangan bahwa setiap siswa mungkin menggunakan seperangkat jenis kecerdasan yang berbeda-beda untuk belajar konsep dan keterampilanketerampilan matematika, tidak hanya kecerdasan logis-matematis (Adams, 2000). Kutipan ini menunjukkan bahwa setiap siswa dapat mempelajari matematika menggunakan variasi kecerdasan yang berbeda-beda walaupun matematika dibangun atas dasar pemikiran logis, kritis dan deduktif yang lebih banyak melibatkan kecerdasan logismatematis.

Berdasarkan teori kecerdasan majemuk, seorang siswa akan dapat mempelajari suatu materi dengan baik apabila materi itu disampaikan sesuai dengan kecerdasan yang cocok dengan kecerdasan yang menonjol pada siswa tersebut (Gardner, 1999). Misalnya, seorang siswa yang dominan pada kecerdasan kinestetik akan mudah mempelajari matematika jika diajarkan dan disajikan dalam bentuk ekspresi gerakan; sedangkan jika diajarkan secara logis-matematis, ia akan mengalami 
kesulitan. Oleh karena kecerdasan siswa di dalam kelas beraneka ragam, guru dituntut untuk menggunakan metode, bahan ajar, dan media pembelajaran yang beraneka ragam pula agar setiap siswa dapat dibantu sesuai dengan kecerdasan yang mereka miliki (Armstrong, 2000).

Pada kenyataannya, desain pembelajaran yang dipraktikkan guru kurang memperhatikan keragaman kecerdasan pada diri siswa. Padahal menurut Gardner (2003: 29), hal yang paling penting dalam praktik pembelajaran adalah guru mampu mengenali dan memelihara keragaman kecerdasan siswa karena mereka memiliki kombinasi kecerdasan yang berbeda-beda. Selain itu, banyak kurikulum pembelajaran matematika saat ini yang mencakup terlalu banyak topik pembelajaran yang tidak memfasilitasi keragaman kecerdasan ini sehingga menciptakan kesulitan yang serius dalam kesuksesan siswa (Tezer, Ozturk, \& Ozturk, 2015).

Untuk dapat melibatkan kecerdasan majemuk dalam pembelajaran matematika, diperlukan pembelajaran yang sesuai dengan teori kecerdasan majemuk. Armstrong (2009:64) berpendapat, "Cara terbaik untuk mendekati kurikulum yang menggunakan teori kecerdasan majemuk adalah dengan cara memikirkan tentang bagaimana seseorang dapat menerjemahkan materi yang diajarkan dari jenis kecerdasan yang satu ke jenis kecerdasan yang lain. Hal ini berarti untuk melaksanakan pembelajaran matematika dengan teori kecerdasan majemuk dapat dilakukan dengan cara memikirkan bagaimana sebuah konsep atau keterampilan matematika yang diajarkan, diterjemahkan dari simbol matematis yang merupakan simbol kecerdasan logis-matematis ke dalam simbol kecerdasan lain seperti bahasa, gambar, ekspresi musik dan fisik, interaksi sosial, refleksi diri, dan alam. Oleh karena itu, Armstrong (2009: 65-67) menganjurkan agar pembelajaran didesain dengan cara mempertimbangkan kemungkinan pendekatan kecerdasan yang cocok dengan topik matematika terpilih, memilih dan mengurutkan aktivitas dalam rencana pembelajaran, dan kemudian menerapkannya ke dalam proses pembelajaran.

Studi tentang pengembangan desain pembelajaran berbasis kecerdasan majemuk memang telah banyak dilakukan dengan berbagai fokus penelitian. Meskipun demikian, peneliti belum 
menemukan hasil penelitian yang mendiskusikan secara khusus bagaimana teori kecerdaan majemuk ini diterapkan dalam pembelajaran matematika yang khas pada topik-topik tertentu. Padahal, desain pembelajaran matematika saat ini banyak dikembangkan berdasarkan lintasan belajar (learning trajectory) yang khas melalui kegiatan studi desain riset (design research) dengan menggunakan pendekatan matematika realistik (Gravemeijer \& Cobb, 2006). Desain riset ini dilakukan dengan tujuan untuk menghasilkan sebuah teori pembelajaran lokal (Local Instructional Theory/LIT). LIT sendiri merupakan suatu teori yang mendeskripsikan dugaan tentang lintasan belajar pada topik tertentu, rangkaian aktivitas pembelajaran dan cara-cara yang digunakan untuk mendukung pembelajaran tersebut (Gravemeijer, 2004).

Banyak dari LIT yang dikembangkan dengan menggunakan pendekatan matematika realistik terindikasi mampu mendukung keterlibatan kecerdasan majemuk siswa. Di Indonesia sendiri, hasil ini, sebagai contoh, dapat dilihat dari penelitian Bustang dkk (2013), Fatoni dkk (2015), Salmah \& Putri (2015), dan Wijaya (2008). Melalui konteks permainan tradisional yang digunakan Fatoni dan Wijaya, misalkan, siswa terlibat secara aktif dalam kegiatan permainan (kecerdasan kinestetik), berdiskusi menyampaikan pendapat hasil kerjasama kelompok (kecerdasan verbal, interpersonal), merepresentasikan hasil kerja kelompok dalam bentuk gambar (kecerdasan visual/spasial), melakukan aktivitas penalaran matematika untuk menyelesaikan masalah yang diajukan (kecerdasan logis-matematis), dan melakukan kegiatan refleksi atas permainan yang telah dilakukan (kecerdasan intrapersonal). Secara teori, karakteristik pendekatan matematika realistik juga mendukung keterlibatan kecerdasan majemuk siswa dalam pembelajaran. Karakteristik penggunaan konteks (use of context), sebagai contoh, dapat diterapkan dengan memperhatikan penggunaan contoh masalah yang berkaitan dengan lingkungan sekitar atau makhluk hidup untuk mendukung keterlibatan kecerdasan naturalistik, sedangkan karakteristik interaktivitas (Interactivity) diterapkan untuk mendukung keterlibatan kecerdasan interpersonal dan intrapersonal siswa. Melihat potensi ini, peneliti berargumen sangat mungkin dikembangkan desain 
pembelajaran matematika realistik yang melingkupi semua jenis jenis kecerdasan majemuk termasuk di dalamnya kecerdasan musikal dan kecerdasan naturalistik.

Salah satu topik spesifik dalam pembelajaran matematika di tingkat sekolah dasar yang banyak dikembangkan adalah pengukuran luas permukaan dan volume bangun ruang sederhana (kubus dan balok), seperti melalui aktivitas visualisasi spasial (Revina \& van Gallen, 2011; Sack, 2013), dan aktivitas menemukan hubungan antara luas permukaan dan volume bangun ruang (Taylor \& Jones, 2013). Pada tingkat sekolah dasar, konsep tentang pengertian volume perlu ditanamkan kepada siswa terlebih dahulu sebelum mereka melakukan investigasi terhadap penemuan cara mencari volume bangun ruang itu sendiri. Konsep ini dapat ditanamkan dengan memberikan pengalaman bagaimana membandingkan dua benda dengan menanyakan mana yang lebih besar. Pembelajaran dapat dimulai dengan diskusi seperti dengan pertanyaan: mana yang biasanya lebih banyak membutuhkan air hingga penuh, bak mandi atau bak kamar kecil. Melalui diskusi interaktif, siswa akan mengemukakan ide jawaban sesuai dengan pengalaman yang telah mereka peroleh, seperti dengan menduga isi air yang lebih banyak ditinjau dari bentuk dan ukuran masing-masing jenis bak atau memperkirakan berapa kali mereka memindahkan air dari sumur ke kedua jenis bak itu. Hal-hal semacam ini sejalan dengan Panhuizen (2005:54) yang mengungkakan bahwa dalam membelajarkan volume, siswa perlu diberi pengalaman membandingkan isi bendabenda yang berguna untuk mencapai pemahaman tentang konsep volume. Setelah siswa paham tentang konsep volume bangun ruang, pembelajaran dapat dilanjutkan dengan menginvestigasi bagaimana cara menemukan volume bangun ruang. Media seperti kubus satuan dapat digunakan sebagai unit terkecil pembentuk sebuah bangun ruang seperti balok/kubus. Dengan mengidentifikasi hubungan panjang, lebar, tinggi balok/kubus dengan banyak kubus satuan yang dibutuhkan untuk memenuhi sebuah model balok/kubus, diharapkan siswa dapat menemukan sendiri rumus volume balok dan kubus.

Dengan pendekatan matematika realistik, masalah-masalah sehari-sehari yang telah dikemukakan di atas dapat menjadi konteks untuk mulai melibatkan 
siswa dalam aktivitas untuk menemukan konsep volume bangun ruang sampai pada menemukan rumus volume bangun ruang. Peran masalah-masalah tersebut sebagai konteks dalam hal ini seperti yang diungkapkan Treffers dan Goffree (dalam Wijaya, 2011:33) bahwa konteks berperan sebagai alat untuk membentuk konsep (concept forming), yang dalam hal ini konsep pengertian volume bangun ruang, dan konteks sebagai alat untuk mengembangkan model (model forming), yang dalam hal ini adalah strategi-strategi untuk menemukan kembali rumus atau cara untuk mencari volume bangun ruang. Untuk selanjutnya, aktivitas-aktivitas tersebut dapat dirancang dengan memperhatikan kedelapan jenis kecerdasan majemuk seperti yang teah diungkapkan Gardner.

Berdasarkan latar belakang yang telah diuraikan, maka pertanyaan dalam penelitian ini adalah "Bagaimana desain pembelajaran matematika realistik pengukuran luas permukaan dan volume bangun ruang sisi datar yang melibatkan kecerdasan majemuk untuk siswa Sekolah Dasar?"

Penelitian ini merupakan penelitian desain riset (design research). Gravemeijer \& Cobb (2006), design research terdiri dari tiga tahap yaitu preparing for the experiment, the design experiment dan the retrospective analysis. Penelitian pada tahap II ini dilaksanakan di kelas 5 sebanyak 6 siswa dari MI Faqih Hasyim, Sidoarjo

Tahap I: Desain Pendahuluan (Preliminary design)

Gravemeijer \& Cobb (2006) menjelaskan bahwa tujuan utama pada tahap ini adalah memformulasikan local instructional theory (HLT) yang dielaborasi dan diperbaiki selama pelaksanaan eksperimen. HLT sifatnya dinamis dan dapat disesuaikan dengan strategi berpikir siswa yang terjadi pada saat design experiment . Oleh karena itu, langkah pertama yang harus dilakukan pada tahap ini adalah mengkaji literatur pengukuran volume dan luas permukaan balok dan kubus, pendekatan PMRI, kurikulum 2013 dan metode design research sebagai landasan dalam mendesain lintasan belajar. Secara terperinci, hal-hal yang dilakukan dalam tahap ini adalah (1) menganalisis tujuan pembelajaran, (2) menentukan dan menetapkan kondisi awal penelitian, (3) mendesain dan mendiskusikan konjektur atau HLT yang akan dikembangkan, (4) 
menentukan karakter kelas dan peran guru.

Tahap II: Percobaan Pembelajaran (teaching experiment)

Kegiatan yang dilakukan pada tahap kedua ini adalah mengimplementasikan desain pembelajaran yang telah didesain pada tahap pertama. Ada 2 siklus pada tahap ini yaitu pilot experiment sebagai siklus 1 dan teaching experiment sebagai siklus 2. Pilot experiment dilaksanakan untuk mengujicobakan rancangan HLT yang sudah dibuat. Siswa yang dilibatkan dalam pilot experiment hanya enam siswa, yang kelasnya berbeda dengan kelas yang dilibatkan dalam teaching experiment. Enam siswa tersebut dipilih oleh guru sehingga dapat mewakili siswa berkemampuan tinggi, sedang, dan rendah. Dalam hal ini, peneliti berperan sebagai guru. Tahap ini bertujuan untuk meningkatkan kualitas HLT yang telah didesain sehingga diperoleh HLT yang lebih baik untuk diterapkan pada siklus 2 . Paper ini melaporkan hanya sampai pada hasil pilot experiment.

Tahap III: The Retrospective analysis

Tujuan dari retrospective analysis secara umum adalah untuk mengembangkan local instructional theory . Pada tahap ini, semua data yang diperoleh selama teaching experiment dianalisis dan hasilnya digunakan untuk merencanakan kegiatan ataupun untuk mengembangkan rancangan pada kegiatan pembelajaran berikutnya. HLT berfungsi sebagai acuan utama untuk menentukan hal-hal apa saja yang menjadi fokus dalam melakukan analisis. HLT kemudian dibandingkan dengan keadaan riil siswa dalam hal ini strategi dan proses berpikir siswa yang benar-benar terjadi saat pembelajaran. Hal yang dianalisis tidak hanya hal-hal yang mendukung HLT melainkan juga contoh yang kontradiksi dengan konjektur yang didesain.

Adapun rancangan penelitian dapat digambarkan sebagai berikut.

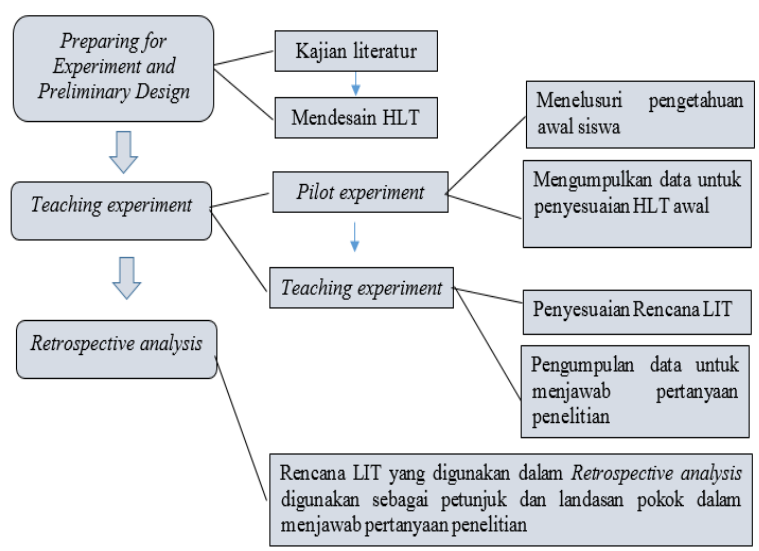

Gambar 1. Rancangan Penelitian Desain Riset

\section{HASIL DAN PEMBAHASAN}

Penelitian ini menghasilkan lintasan belajar penyelesaian persamaan kuadrat yang selanjutnya dapat berkontribusi 
dalam mengembangkan Local Instructional Theory (LIT). Selanjutnya hasil dan pembahasan dari tahapantahapan tersebut diuraikan sebagai berikut.

\section{Preliminary \\ Design \\ (Desain}

Pendahuluan)

Pada tahap yang pertama, peneliti mengembangkan hypothetical learning trajectory (HLT). Gambaran aktivitas yang dikembangkan dalam HLT pada tahap pertama adalah siswa dapat memahami melalui aktivitas menggambar jaring-jaring kubus dan balok melalui aktivitas menggulung model kubus dengan warna masing-masing sisi kubus yang berbeda-beda dengan tujuan siswa dapat menentukan sebanyak mungkin susunan jaring-jaring kubus dan balok. Kedua, siswa dapat menyelesaikan masalah kebutuhan kertas pembungkus pada masalah yang disajikan dengan tujuan Siswa dapat menggunakan pemahaman luas persegi dan persegi panjang untuk menentukan luas jaringjaring kubus/balok. Ketiga, menentukan luas seluruh permukaan box pembungkus dengan tujuan siswa dapat mengkonstruksi rumus luas permukaan kubus dan balok. Sedangkan pada materi Volume kubus dan balok aktivitas pertama yang dikembangkan adalah Menggambar susunan 'nasi kotak' menyerupai balok yang terletak di atas meja dengan tujuan Siswa dapat menyajikan susunan objek tiga-dimensi ke dalam bentuk gambar duadimensi berdasarkan atas posisi pandang yang berbeda (top view, side view, dan front view) dan memahami bagian interior kubus/balok. Kedua, Menyusun miniatur bangunan dengan menggunakan model batu bata dengan tujuan Siswa dapat menyusun balok yang terdiri dari balok satuan berdasarkan gambar pandangan yang berbeda (top view, side view, dan front view). Ketiga, Menghitung banyak model batu bata dalam sebuah konstruksi bangun ruang berbentuk balok dengan tujuan siswa dapat menghitung banyak kubus satuan (model batu bata) berdasarkan gambar pandangan dari atas, samping, dan depan berdasarkan pengalaman aktivitas sebelumnya dengan memperhatikan banyak kubus satuan yang terdapat pada tiap lapisan (layer). Keempat, Memprediksi banyak 'nasi kotak' yang tersusun di atas meja (packaging activity) dengan tujuan siswa mampu memperkirakan banyak nasi kotak (volume) dengan memperhatikan banyak nasi kotak pada tiap lapis (layer) dan banyak lapisan sehingga mampu mengkonstruksi cara mencari volume 
yang paling efektif. Kelima, Memprediksi banyak nasi kotak maksimal yang dapat dimuat oleh sebuah box dengan ukuran tertentu (filling activity) dengan tujuan siswa mampu memperkirakan banyak nasi kotak (volume) yang bisa dimuat oleh sebuah box dengan memperhatikan ukuran panjang, lebar, dan tinggi box. Menata ulang sejumlah susunan nasi kotak dengan susunan banyak lapisan (layer) yang berbeda-beda dengan tujuan siswa dapat menentukan luas permukaan yang berbeda untuk volume sebuah bangun ruang yang sama, lalu menentukan luas mana yang paling kecil/besar. Terakhir, membandingkan banyak pasir yang dibutuhkan oleh bangun ruang yang dibentuk oleh 2 buah kertas dengan ukuran yang sama terakhir dengan tujuan diberikan dua buah kertas berukuran sama (misalkan p x 1), siswa memberikan justifikasi manakah yang akan memberikan volume lebih besar: bangun ruang yang dibentuk dengan merekatkan sisi dengan panjang $\mathrm{p}$ atau l) serta membangun pemahaman bahwa dua bangun ruang yang memiliki volume yang sama tidak selalu memiliki luas permukaan yang sama.

Kegiatan penyusunan HLT ini didahului dengan kegatan analisis terhadap kurikulum yang bertujuan agar pembelajaran yang didesain sesuai dengan kurikulum matematika yang berlaku untuk kelas 5 SD sebagai subjek dalam kegiatan pembelajaran. Analisis meliputi penentuan materi ajar, tujuan pembelajaran, dan indikator pembelajaran.

Standar kompetensi dan kompetensi dasar yang menjadi acuan dalam penyusunan rencana pembelajaran secara berturut-turut adalah menentukan volume kubus dan balok dan menggunakannya dalam pemecahan masalah dan menghitung volume kubus dan balok. Dari kompetensi dasar tersebut dirumuskan tujuan pembelajaran dan indikator keberhasilan pembelajaran. Karena fokus dari pembelajaran adalah membahas konsep volume bangun ruang dan cara mencari volume balok dan kubus, maka tujuan pembelajaran yang diharapkan adalah dengan menggunakan kubus satuan dan beras, siswa dapat membandingkan isi antara volume kubus dan balok, dan siswa juga dapat menemukan volume kubus dan balok dengan menggunakan kubus satuan yang diberikan, dengan indikator pembelajaran yaitu membandingkan isi antara kubus atau balok dengan dan menemukan rumus volume kubus dan 
balok dengan menggunakan kubus satuan yang diberikan.

Setelah menentukan tujuan dan indikator pembelajaran, kegiatan selanjutnya adalah melakukan analisis terhada hasil pretest siswa tentang materi luas permukaan balok dan kubus serta volumenya. Dalam pretes ini, siswa diberi seperangkat soal megenai jaring-jarng kubus, volume kubus, dan luas permukaannya yang disajikan dalam bentuk soal kontekstual. Pretest diberikan kepada 6 siswa subjek small group. Berikut ini adaah salah satu hasil pretest dari seorang subjek.

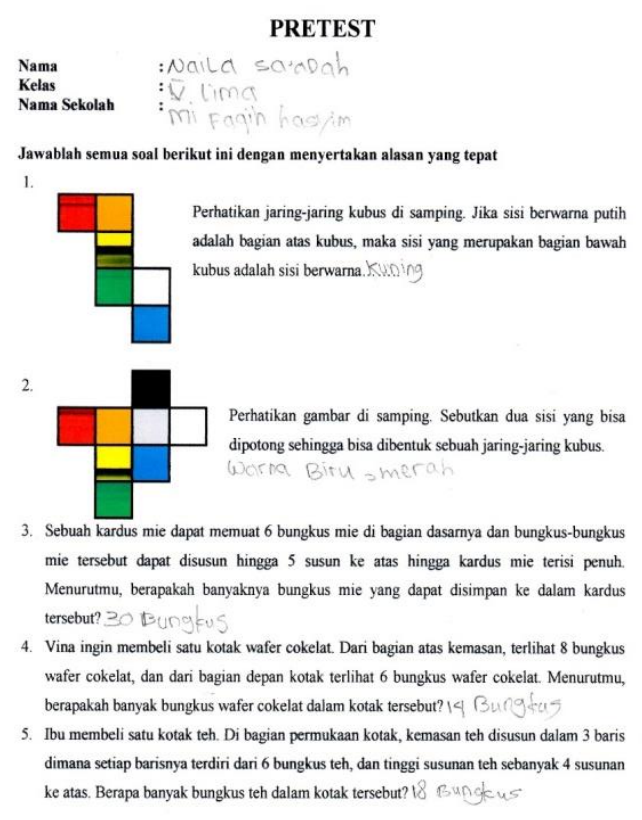

Gambar 2. Contoh hasil pretest siswa

Dari hasil di atas, tampak bahwa kemampuan spasial siswa, yang merupakan indikator kecerdasan visual/spasial, belum tampak dengan baik, dibuktikan dengan jawaban yang salah pada soal no1 dan 2. Hasil ini menunjukkan perlu adanya desain aktivitas yang dapat melatih siswa mengembangkan kecerdasan vsual/spasial, yang merupakan kecerdasan penting untuk dilibatkan dalam menyelesaikan masalah volume dan luas permukaan bangun ruang. Sementara itu, hasil dari soal no 4 dan 5 secara khusus menunjukkan bahwa siswa mengalami kendala dalam menyelesaikan masalah kontekstual terkait bangun ruang, tampak bahwa siswa pada no 5 salah menjawab. Ada dugaan siswa sekedar melakukan operasi kali dan jumlah tanpa ada pertimbangan kontekstual yang mendukung, sehingga memperoleh jawaban 18. Hasil ini mengindikasikan perlu adanya desain aktivitas yang mendukung siswa melibatan kecerdasan visual/spsialnya untuk menentukan hubungan antara panjang, lebar, dan tnggi suatu balok/kubus dalam rangka mencari isi atau volumenya.

Dari catatan kami pada saat melaksanakan wawancara dan observasi kelas di kelas guru mitra, siswa sudah mulai terlihat aktif dalam kegiatan 
pembelajaran, baik pada saat tanya jawab dengan guru, maupun pada saat diskusi dalam kelompok. Hal ini menunjukkan bahwa interaktivitas siswa (student's interactivity) sebagai salah satu karakteristik PMRI mulai muncul. Oleh karena itu, dalam desain pembelajaran volume balok dan kubus ini, interaktivitas akan kembali dimunculkan dalam kegiatan pembelajaran, yaitu pada saat kegiatan awal ketika guru melakukan tanya jawab materi sebagai stimulus pembelajaran, kegiatan inti ketika siswa bekerja dalam kelompok dan presentasi hasil kerja kelompok, dan kegiatan akhir ketika guru bersama siswa menyimpulkan pembelajaran. Serangkaian kegiatan ini bertujuan agar siswa dapat mengkonstruksi sendiri pemahaman mereka terhadap masalah yang diberikan sehingga bermanfaat untuk bergerak ke proses matematisasi selanjutnya (student's contribution).

Karakteristik lain, keterkaitan antar pengetahuan/konsep dengan materi lain (intertwining of learning strands), diharapkan muncul pada saat siswa menginvestigasi cara mencari volume balok dan kubus. Pengetahuan yang dimaksud dapat berupa keterampilan perkalian dan konsep persegi panjang/persegi beserta cara mencari luasnya. Dalam kaitannya dengan proses matematisasi yang dibangun oleh siswa melalui penggunaan model (use of model) selama pembelajaran, maka disusunlah sebuah iceberg materi volume balok dan kubus seperti pada gambar 1.

Untuk mencapai tujuan tersebut, dikembangkan juga perangkat pembajaran yang terdiri dari rencana pelaksanaan pembelajaran (RPP), lembar aktivitas siswa (LAS), pedoman guru, lembar tes.

Secara terperinci, HLT yang telah disusun disajikan dalam tabel berikut ini.

Tabel 1 Hipotesis rancangan lintasan belajar (hypothetical learning trajectory) pengukuran luas permukaan dan volume bangun ruang

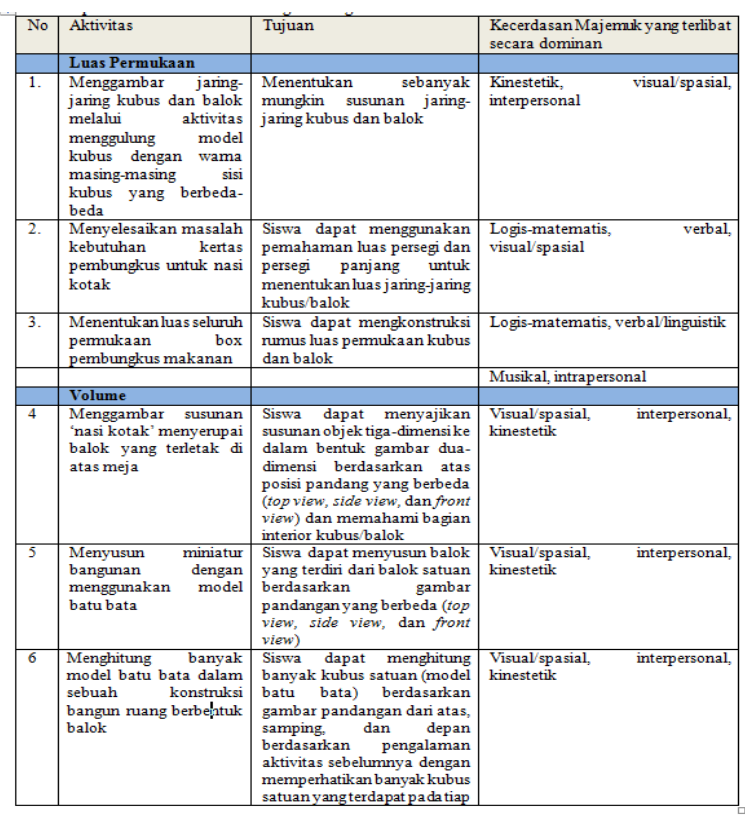




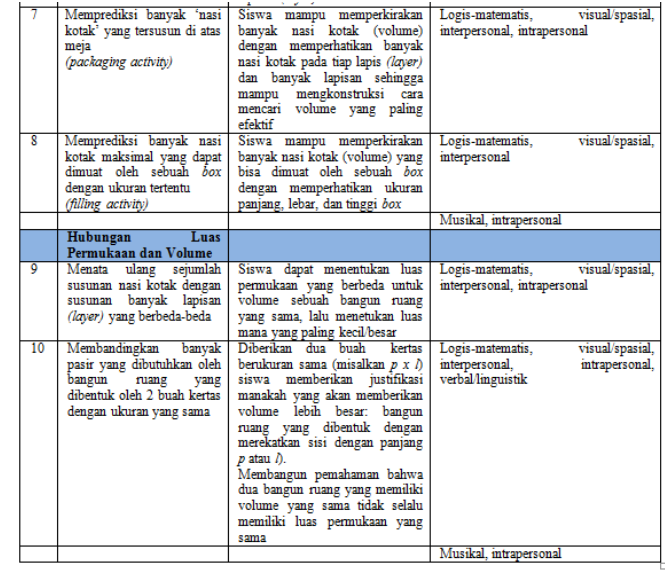

\section{Pilot experiment}

Pilot experiment dilaksanakan di MI Faqih Hasyim dengan melibatkan 6 siswa kelas V. Kegiatan ini dilaksanakan selama 5 kali pertemuan, dengan rinciam kegiatan sebagai berikut: 1) pretest, 2) menemukan susunan jaring-jaring kubus dan balok melalui aktivitas enggulung model kubus atau balok, 3) menemukan konsep volume melalui aktivitas 'kotak mana yang lebih besar?', 4) menentukan isi kubus berdasarkan gambar tampak depan, belakang, dan samping, 5) membungkus tanah liat untuk menentukan luas permukaan balok, 6) menentukan luas permukaan balok dan kubus berdasarkan jaring-jaringnya, 7) menemukan strategi menentukan volume balok kubus melalui masalah 'nasi kotak', dan 8) menyusun model susunn kubus dan balok dari 'model kubus satuan' dengan berbgai ukuran, namun dengan volume yang tetap.

Aktivitas 1: Menemukan susunan jaring-jaring kubus dan balok melalui aktivitas menggulung model kubus atau balok

Dalam aktivitas ini siswa diajak untuk menentukan jaring-jaring balok dan kubus, menemukan sejumlah kemungkinan banyaknya jaring-jaring balok dan kubus, dan menggambar jaringjaring balok dan kubus,. Untuk menemukan jaring-jaring kubus, siswa diajak untuk melakukan aktivitas menggulung model kubus yang telah diwarnai berbeda pada setiap sisinya, kemudian membuat jejak berbentuk persegi dari setiap sisi yang menempel pada kertas gambar. Tujuan pewarnaan sisi kubus yang berbeda ini adalah agar siswa mampu mengenali sisi yang telah digambarkan jejaknya di kertas sehingga tidak ada sisi yang digambarkan jejaknya lebih dari satu kali. Aktivitas yang sama juga dapat dilakukan untuk menemukan jaring-jaring balok. Berikut ini contoh alur penemuan jaring-jaring. 


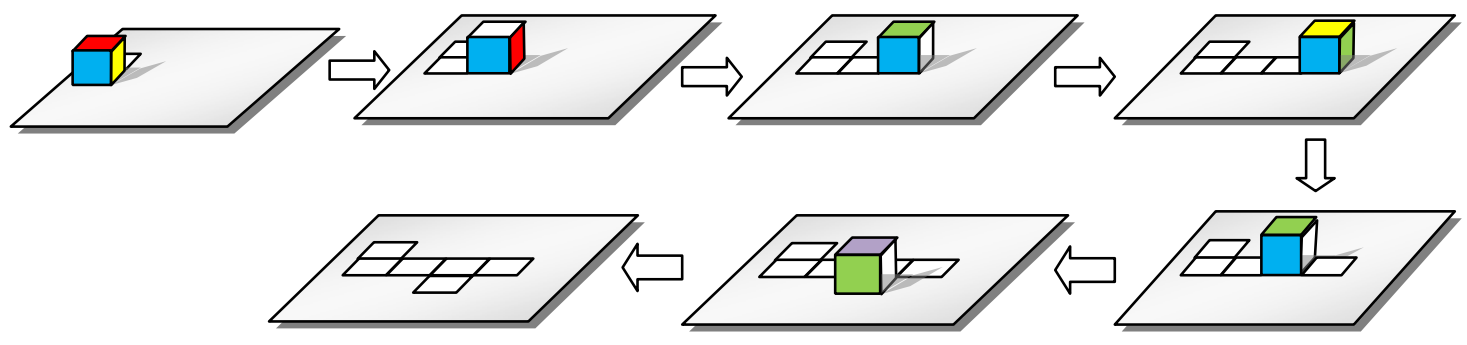

Gambar 3. Alur Aktivitas Penemuan Jaring-Jaring Kubus

Dalam aktivitas di atas, kecerdasan kinestetik dan visual/spasial lebih banyak terlibat karena berhubungan dengan aktivitas menggulung balok dengan gerakan tangan dan aktivitas menggambar hasil penemuan jaring-jaring kubus. Hasil pekerjaan siswa pada aktivitas ini ditunjukkan oleh gambar berikut ini.

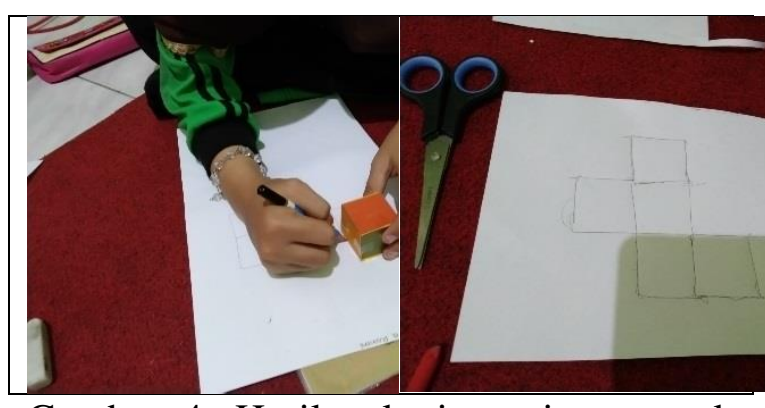

Gambar 4. Hasil pekerjaan siswa untuk aktivitas pelibatan kecerdasan visual/spasial

Dari semua pola jaring-jaring kubus yang ditemukan siswa, hanya pola 1-4-1 yang muncul dengan model 1 dan 6 yang paling banyak muncul. Pola 1-4-1 adalah pola jaring-jaring kubus yang terdiri dari rangkaian empat bidang sisi persegi dalam satu baris di bagian tengah yang kemudian diikut dengan 1 sisi persegi di sisi kiri dan kanan. Sementara itu, jaring jaring kubus pola dengan pola 2-3-1, 2-22, dan 3-3 tidak muncul dalam respon siswa.
Aktivitas 2: menemukan konsep volume melalui aktivitas 'kotak mana yang lebih besar?'

Aktivitas ini dilakukan siswa dengan tujuan untuk memahami konsep volume balok dan kubus. Guru memberikan instruksi untuk menggunakan beras dan kubus satuan untuk membandingkan mana yang lebih besar antara balok atau kubus.

Beberapa temuan terkait dengan kegiatan membandingkan ini terjadi. Ketika membandingkan dengan beras, beberapa kelompok mengeluh bahwa beras yang disediakan tidak cukup untuk mengisi penuh kedua benda yang dibandingkan. Kelompok lain ada yang mengisi beras ke dalam benda yang lebih kecil terlebih dahulu (dalam hal ini kubus), sehingga ketika beras dituang ke benda yang lebih besar (balok), beras tidak memenuhi benda tersebut. Awalnya siswa bingung sehingga mereka menambah muatan beras ke dalam benda yang lebih besar itu. Bagaimanapun, setelah guru membimbing siswa bagaimana cara membandingkan, siswa akhirnya tahu mana yang lebih besar. 


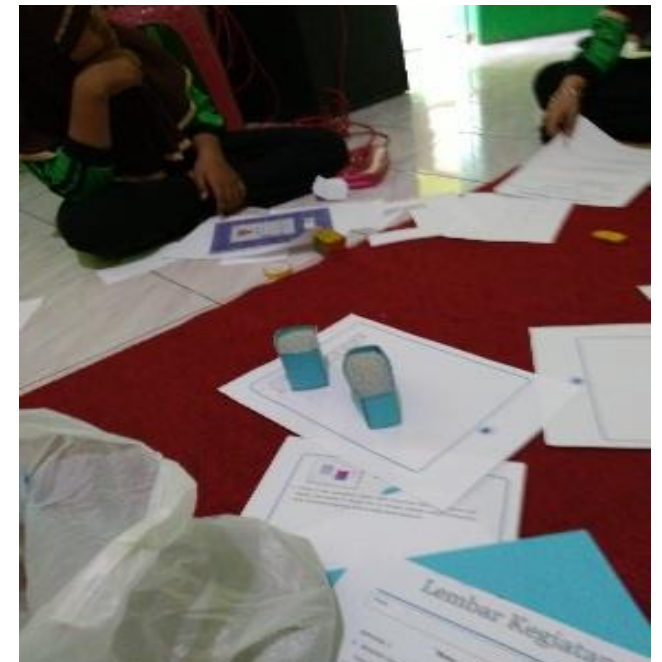

Gambar 5. Aktivitas membandingkan volume balok dan kubus dengan menggunakan beras dan kubus satuan

Untuk kegiatan membandingkan dengan menggunakan kubus satuan sebagai pembanding, rata-rata siswa telah melakukan dengan benar. Mereka dengan mudah mengetahui bahwa balok membutuhkan 9 kubus satuan, sedangkan kubus membutuhkan 8 kubus satuan, dengan memasukkan kubus-kubus satuan tersebut ke masing-masing bangun. Hal ini membawa mereka pada kesimpulan bahwa balok lebih besar daripada kubus. Berikut ini adalah beberapa variasi jawaban siswa di aktivitas 1 .
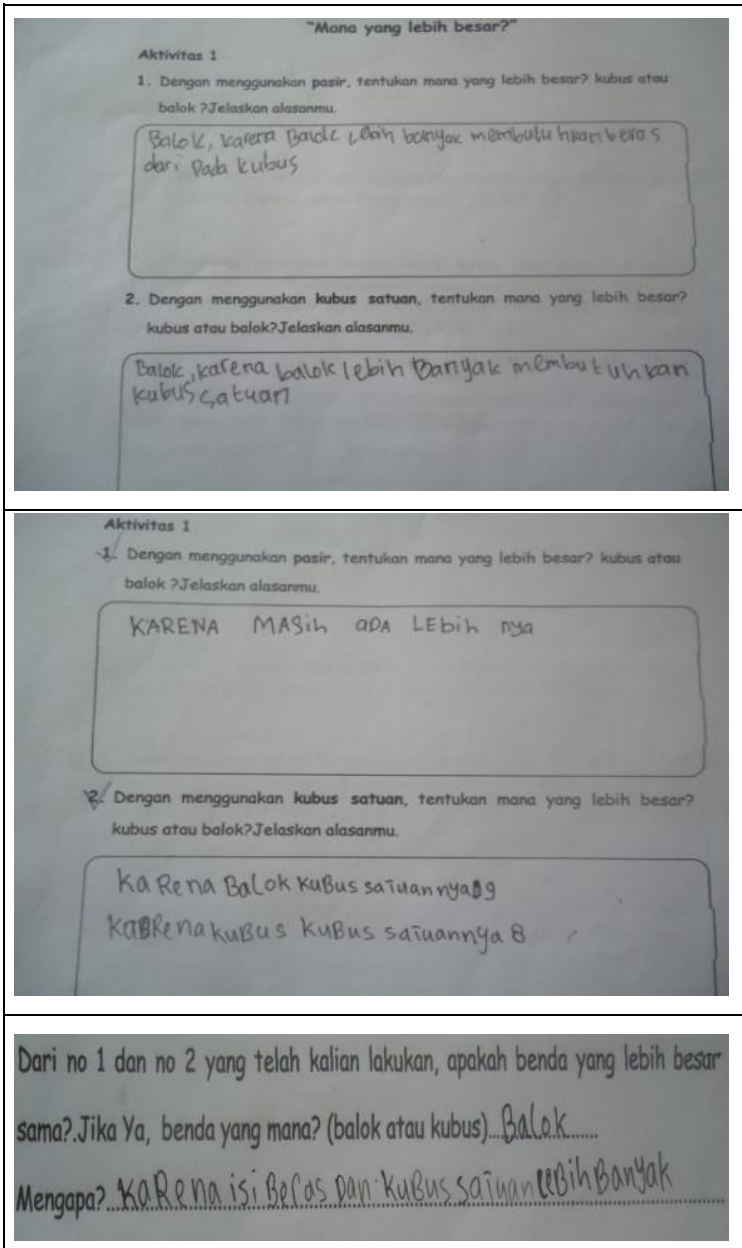

Gambar 6. Variasi jawaban siswa di aktivitas 1

Dari pertanyaan 1 dan 2 di aktivitas 1, rata-rata siswa sudah berhasil menjawab dengan benar bahwa balok dengan ukuran $3 \times 1 \times 3$ lebih besar daripada kubus dengan ukuran $2 \times 2 \times 2$ dengan variasi jawaban seperti di atas. Meskipun beberapa kelompok kesulitan menuliskan kesimpulan jawaban pertanyaan 1 dan 2, ada beberapa kelompok menuliskan bahwa balok lebih besar dengan alasan isi balok, baik dengan beras maupun kubus satuan lebih banyak daripada kubus. 
Aktiivitas 3: menentukan isi kubus berdasarkan gambar tampak depan,

\section{belakang, dan samping}

Permasalahan ini ditujukan untuk membangun visual siswa melalui kegiatan penyusunan model kubus sebanyak 12 buah dan menggambarkan penampakan sususan tersebut dari berbagai arah. Dalam kegiatan ini kecerdasan majemuk yang dilibatkan adalah kecerdasan visual melalui aktivitas pengamatan dan menggambarkan apa yang mereka lihat dari berbagai arah yang berbeda. Diharapkan melalui aktivitas ini siswa dapat membangun pengetahuan spasial mereka yang diperlukan dalam mengkontruksi konsep luas permukaan dan volume kubus dan balok.

\section{Aktiivitas 4: menyelesaikan masalah} yang berkaitan untuk menentukan luas permukaan balok,

Dalam aktivitas ini, siswa bekerja sama menyelesaikan masalah dalam tabel berikut.

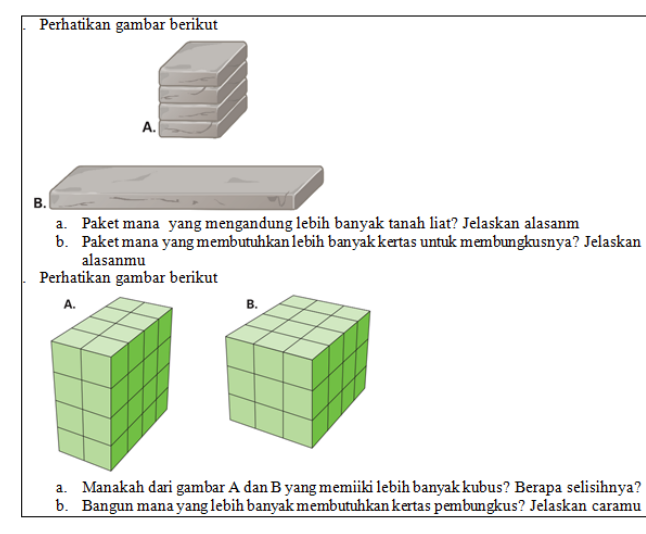

Dalam merespon masalah dalam aktivitas 3, siswa memberikan jawaban yang berbeda-beda. Pada masalah pertama, sebagain siswa menganggap gambar A mengandung lebih banyak tanah liat, karena tampak lebih besar daripada gambar B, sedangkan gamabr B lebih banyak membutuhkan kertas pembungkus karena terlihat lebih panjang. Jawaban-jaaban seperti ini mengindikasikan bahwa dalam membandingkan volume dan luas permukaan, siswa belum secara komprehensif membandingkan ukuranukuran panjang, lebar, dan tinggi masingmasing bangun, sehingga tidak ditemukan jawaban yang logis secara matematis.

Pada masalah yang kedua, untuk membandingan mana yang lebih besar, siswa menggunakan cara menghitung per layer lalu mengalikan dengan banyak layeryang ada pada bangu tersebut. Hal ini tampak lebih mudah karena dalam 
gambar disajikan kubus satuan yang menyusun bangun tersebut, yang tidak ditemukan pada gambardi bangun rang dalam soal 1. Berikut petikan wawancara yang mengindikasikan hal ini.

Peneliti : mengapa yang ini kamu bisa membandingkan, sedangkan yang soal 1 kamu tidak bisa?

Siswa 1 : soal ini ada gambar-gambar yag kecil (kubus satuan), kalau yang gambar di soal nol tidak ada gambar-gambar kecil, jadi susah melihat mana yang lebih besar

Peneliiti : Sekarang coba bandingkan mana yang lebih besar?

Siswa 1 : Gambar 1 ada 32 ginian (kubus satuan), kalau yang gambar 2 ada 33 ginian [salah perhitungan karena salah mengalikan $3 \times 4$ sebanyak tiga layer, ada 33, seharusnya 36] . karena selisih 1, jadi gambar B yang lebih besar.

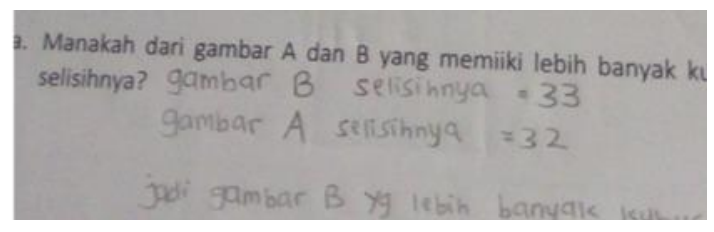

Gambar . Respon siswa 1 pada masalah 2

Sebagai kesimpulan, dalam membandingkan volume dua bangun datar, pada dasarnya siswa telah memapu menggunakan konsep volume dengan benar apabila disajikan dalam bentuk susunan kubus satuan, sedangkan siswa menemukan kesulitan membandingkan volume bangun ruang yang tidak disajikan dalam bentuk susunan kubus satuan.

\section{Aktiivitas 5: menentukan luas} permukaan balok dan kubus

\section{berdasarkan jaring-jaringnya,}

Dalam kegiatan ini, siswa merangkai berbagai bentuk model persegipanjang dengan berbagai ukuran ke dalam bentuk jaring-jaring kubus atau balok. Ukuran model persegi/persegipanjang yang disajikan adaah $2 \times 2,2 \times 3,3 \times 3,3 \times 3,3 \times 4$, $4 \times 4$, dan $4 \times 5$. Setelah merangkai jaringjaring, siswa diminta untuk menentukan total luas model ukuran persegipanjang/persegi yang telah dipilih.

Masing-masing dari gambar berikut menunjukkan model persegi panjang yang digunakan dan hasil susunan sebuah jaring-jaring bak yangtelah berhasil dijiplak ke dalam lembarkerja siswa

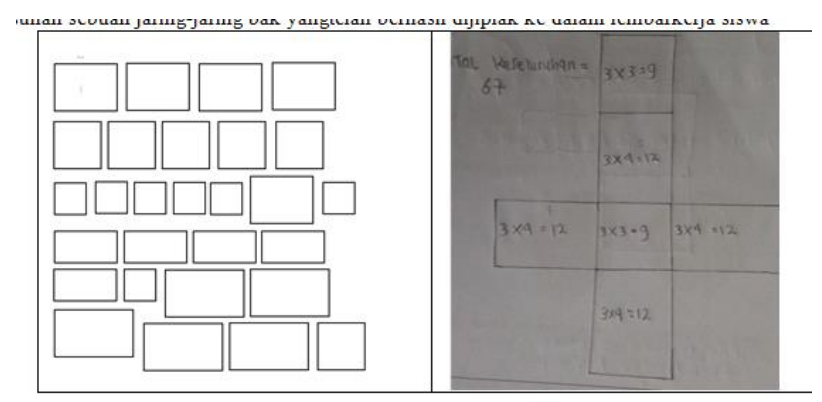

Gambar Model persegipanjang dan susunan jaring-jaring balok Tantangan aktivitas ini adalah menentukan kombinasi yang cocok untuk dibuat jaring-jaring balok. Pada 
kesempatan pertama, siswa cenderug untuk sekedar mengambil model yang ada dan mendekatkan satu sama lain, tanpa memperhatikan ukuran yang sesuai. Selain itu, siswa juga tidak menyadari bahwa sebenarnya mereka cukup mencari maksimal 3 pasang ukuran persegipanjang saja sehingga jaring-jaring yang disusun tidak benar.

Setelah selesai menyusun jajar genjang, siswa diminta untuk menghitung luas total persegi/persegi panjang yang dibutuhkan.

Dalam kegatan ini, siswa dipandu untuk meringkas cara yang mereka lakukan dengan mempertimbangkan dua model persegipanjang yang berkuran sama untuk dikalikan 2, dan dijumlahkan dengan luasan yang lain untuk menuju rumus luaspermukan balok, $2 \mathrm{p}+2 \mathrm{l}+2 \mathrm{t}$

Aktivitas 6: menemukan strategi menentukan volume balok kubus melalui masalah 'nasi kotak',

Dalam aktivitas ini, siswa diminta menyelesaikan masalah kontekstual berikut.

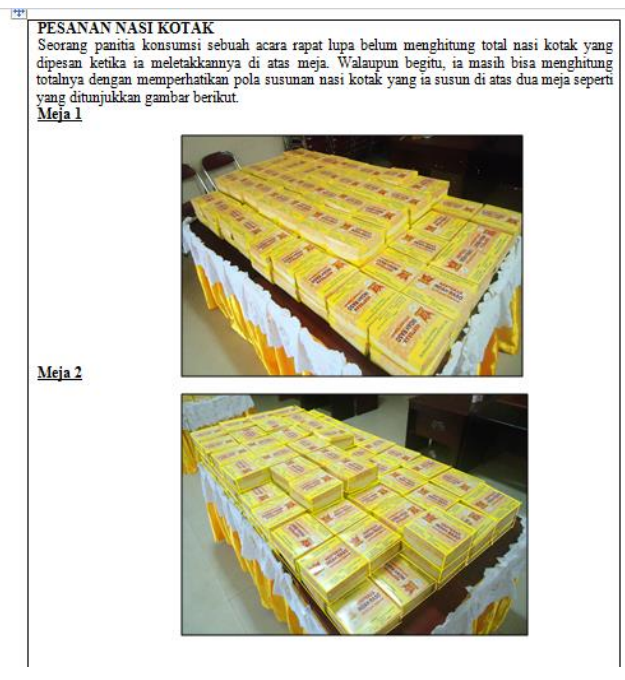

Kesalahan siswa rata-rata hanya terletak pada kekurangcermatan membuat perhitungan seperti Berikut ini disajikan dua macam penyelesaian siswa untuk soal ini.

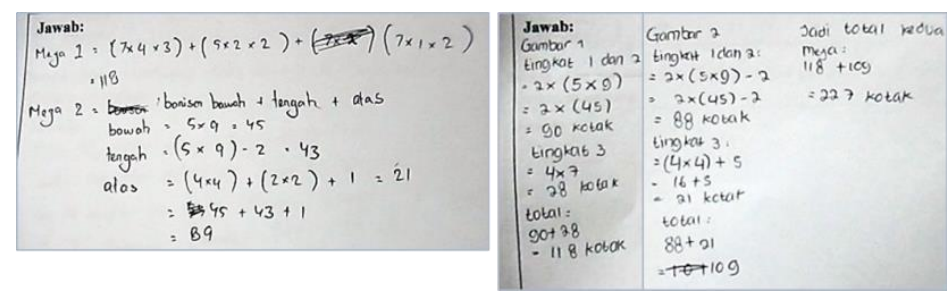

Gambar Respon siswa pada masalah nasi kotak

Dari gambar di atas dapat diungkapkan baik siswa mampu menerapkan prosedur matematika dengan baik berdasarkan model gambar yang diberikan. Strategi penyelesaian dilakukan dengan efektif dengan menggunakan konsep luas untuk mencari banyak nasi kotak pada masingmasing teras. Namun, demikian dari analisis dokumen, peneliti menemukan jawaban seperti gambar bagian kiri dimana terjadi kecerobohan siswa 
melakukan operasi simbolik dalam proses perhitungan sederhana. Selain itu, siswa dalam respon ini tidak sepenuhnya menjawab pertanyaan dengan menuliskan total nasi kotak seperti yang ditanyakan dalam soal. Untuk alasan inilah, beberapa siswa yang tidak berhasil memperoleh skor penuh.

Secara umum, hasil respon siswa daam kegiatan ini menunjukkan strategi siswa yng mengarah pada cara mencari volume balok yang paling sedehana. Dimana hasil diskusi mengarah pada rumus panjang $\mathrm{x}$ lebar x tinggi.

\section{Aktivitas 7: menyusun model susunan} kubus dan balok dari 'model kubus satuan' dengan berbagai ukuran, namun dengan volume yang tetap.

Pada saat membahas volume balok dan kubus, siswa diajak untuk menemukan rumus volume balok dan kubus serta menggunakannya dalam menentukan volume suatu balok/kubus, memecahkan masalah yang berkaitan dengan balok dan kubus dan menentukan perubahan volume suatu balok/kubus jika ukuran rusukrusuknya diubah. Dalam menemukan rumus volume balok dan kubus, siswa diberikan sejumlah model kubus satuan untuk disusun menjadi sejumah model balok dan kubus, kemudian menentukan banyak kubus satuan yang dibutuhkan yang mewakili volume dari setiap model balok/kubus yang telah dibuat. Aktivitas ini banyak melibatkan kecerdasan kinestetik dan visual/spasial karena siswa perlu memindahkan kubus-kubus satuan untuk membentuk model kubus/balok, kemudian menggambarkan sketsa model tersebut.Hasil pekerjaaan pada aktivitas ini dapat dilihat dalam gambar berikut ini.

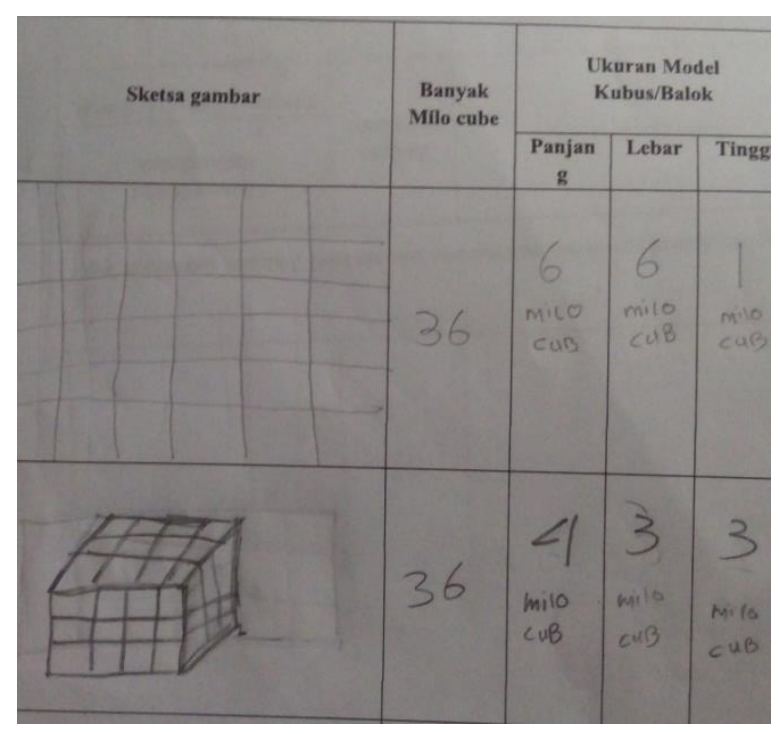

Gambar Gambar susunan balok untuk volume 36 satuan

Pada mulanya siswa tidak memahami cara meggambar bentuk balok yang sesuai dengan banyak kubus satuan yang disusun. Namun, stelah memahami panduan dari guru, tentang arah pandang bagian-bagian pada gambar sebuah balok, siswa mulai membuat sketsa dengan bear, 
meskipun tidak dengan ukuran yang tepat. Hal ini tampak pada gambar di atas.

Siswa juga cenderung menata kubus-kubus satuan sejumlah 36 buah tersebut dengan sekedarnya, tanpa memperhatikan ukuran panjang, lebar, dan tinggi yang sesuai dengan jumlah kubus satua yang disediakan. Setelah berdiskusi, siswa menata ulang kubus satuan menjadi balok dengan ukuran $36 \times 1 \times 1,4 \times 3 \times 3$ dan $6 \times 3 \times 2$, sedangkan ukuran lain seperti $9 \times 4 \times 1,9 \times 2 \times 2$, atau $6 \times 6 \times 1$, tiak ditemukan.

\subsection{Analisis Restropektif}

Setelah kegiatan pembelajaran selesai, kami dan Ibu Fatmawati melakukan analisis retrospektif yang bertujuan untuk merefleksi dan menganalisis proses pembelajaran yang telah dilaksanakan dan juga membandingkan antara desain pembelajaran yang telah dibuat dengan kenyataan yang terjadi pada saat pembelajaran.

Secara garis besar, pembelajaran terlaksana dengan baik sesuai dengan waktu yang direncanakan. Temuan seperti siswa yang kurang fokus terhadap instruksi guru ketika mengerjakan LKK masih menjadi kendala dalam proses pembelajaran. Akibatnya, beberapa kali guru harus datang ke setiap kelompok untuk menginstruksikan kembali aturan mengerjakan LKK. Selain itu, beberapa kelompok masih salah penafsiran dalam menuliskan jawaban ke LKK. Misalnya, ketika siswa menjawab pertanyaan di aktivitas 2 tentang banyak kubus satuan di bagian alas yang seharusnya dijawab 6 buah, beberapa dari kelompok menjawab 3. Hal ini dikarenakan siswa belum bisa membedakan antara panjang balok dengan banyak kubus satuan di bagian alas, meskipun sebelumnya guru telah menerangkan mana yang disebut sebagai bagian alas balok. Selain itu, kami juga menemukan beberapa kelompok pada mulanya masih bingung menentukan perkiraan banyak lapis kubus satuan yang dibutuhkan agar balok penuh. Namun, setelah mendapatkan bimbingan dari guru dan anggota kelompok tersebut paham bahwa istilah banyak lapis adalah banyak “tingkat kubus satuan” yang ada.

Pada aktivitas 1, dari dua benda yang disediakan, ada beberapa kelompok yang mengisi beras ke dalam benda yang lebih kecil terlebih dahulu, sehingga ketika beras dituang ke benda yang lebih besar, beras tidak memenuhi benda tersebut. Awalnya siswa bingung dan menambah muatan beras pada benda yang lebih besar itu. Ada kemungkinan hal ini terjadi 
karena siswa kurang memahami instruksi pada lembar kerja dan konsep "mana yang lebih besar", sehingga yang dilakukan siswa hanya bagaimana caranya agar kedua benda tersebut dapat dipenuhi dengan beras.

Pada aktivitas 2, guru memberikan model balok kepada setiap siswa dengan volume/isi sebenarnya 12 kubus satuan. Tetapi pada saat praktik, guru hanya memberikan 8 kubus satuan dengan tujuan untuk membangun berpikir kritis siswa terhadap kekurangan jumlah kubus satuan yang diperlukannya. Strategi siswa untuk menjawab pertanyaan pertama tentang banyak kubus satuan yang dibutuhkan untuk mengisi penuh bagian alas balok, adalah mengisi kubus satuan pada bagian yang terbawah/alas nya lalu menghitung banyaknya kubus satuan yang diperlukan yaitu 6 kubus satuan. Namun demikian, ada salah satu kelompok yang ternyata sesuai dengan prediksi tim bahwa mereka mengisi kubus satuan pada bangun balok dengan menghitung semua kubus satuan yang telah dimasukan yaitu 8 buah kubus satuan.

Jika dikaitkan dengan desain yang kami rencanakan, situasi di dalam akivitas 1 samapi 7 telah menggambarkan dua karakteristik PMRI yang diharapkan terjadi selama pembelajaran, yaitu student's contribution yang banyak melibatkan pengaruh siswa untuk menemukan sendiri konsep volume dan rumus volume balok dan interactivity yang ditunjukkan dengan terjalinnya komunikasi antar siswa dalam kelompok dan komunikasi antar siswa dengan guru pada saat diskusi kelompok dan presentasi.

Sementara itu, keterkaitan antar materi (intertwining) terjadi ketika siswa menggunakan konsep luas persegi panjang dan konsep perkalian ketika merumuskan cara mencari volume balok dan kubus, sedangkan karakteristik use of model dalam pembelajaran ini ditunjukkan ketika siswa menggunakan beras dan kubus satuan sebagai media bagi siswa untuk bergerak dari konteks masalah balok/kubus di kehidupan sehari-hari ke arah matematika formal, yaitu konsep volume balok dan kubus. Namun demikian, menurut kami ukuran model balok $3 \times 2 \times 2$ tidak cukup membuat siswa berpikir kritis memperkirakan banyak lapis kubus satuan yang dibutuhkan, sehingga semua kelompok dengan mudah menduga akan ada dua lapis dalam balok tersebut. Oleh karena itu, akan lebih baik jika model balok yang digunakan 
berukuran lebih besar agar semakin banyak strategi yang bisa muncul untuk menduga banyak lapis balok.

\section{SIMPULAN}

Desain pembelajaran yang dirangcang dalam penelitian ini mengintegrasikan tujuh kecerdasan ke dalam local instructional theory pada materi volume balok dan kubus. Secara umum aktivitas yang dilakukan dalam pembelajaran ini meliputi aktivitas memahami jaring-jaring balok dan kubus serta menggunakannya dalam menyelesaikan masalah luas permukaan, serta menyusun model susunn kubus dan balok dari 'model kubus satuan' dengan berbagai ukuran untuk menentukan volume balok.kubus. Tahapan selanjutnya dari penelitian ini adalah melaksanakan teaching experiment pada satu kelas (35 siswa) berdasarkan hasil analisis restropektif pada tahap pilot experiment yang telah dilakukan sebelumnya.

\section{DAFTAR PUSTAKA}

[1] Armstrong, T. (2009). Multiple intelligences in the classroom. Ascd.

[2] Bakker, A. (2004). Design Research in Statistics Education on Symbolizing and Computer Tools. Amersfoort: Wilco Press.

[3] Bednar, J., Coughlin, J., Evans, E., \& Sievers, T. (2002). Improving Student Motivation and Achievement in
Mathematics through Teaching to the Multiple Intelligences. Chicago: School of Education, St Xavier University

[4] Bellanca, J. (2008). 200+ Active Learning Strategies and Projects for Engaging Students Multiple Intelligences. Corwin Press.

[5] Bustang, B., Zulkardi, Z., Darmawijoyo, H., Dolk, M., \& van Eerde, D. (2013). Developing a Local Instruction Theory for Learning the Concept of Angle through Visual Field Activities and Spatial Representations. International Education Studies, 6(8), 58-70.

[6] Curry, M., Mitchelmore, M., \& Outhred, L. (2006, July). Development of children's understanding of length, area, and volume measurement principles. In Proceedings 30th Conference of the International Group for the Psychology of Mathematics Education (Vol. 2, pp. 377-384).

[7] Dyke, Van, dkk. 2007. Fundamental of Mathematics, 9th Edition.USA: Thomson Brooks/Cole.

[8] Fatoni, F., Putri, R. I. I., \& Hartono, Y. (2015). Permainan Tradisional Batok Kelapa Dalam Membangun Konsep Pengukuran Panjang Kelas Ii Sd. Jurnal Cakrawala Pendidikan, 1(1).

[9] Gardner, H. (1999). Intelligence reframed: Multiple intelligences for the 21 st century. Basic books.

[10] Gravemeijer, K. (2004). Local instruction theories as means of support for teachers in reform mathematics education. Mathematical thinking and learning, 6(2), 105-128.

[11] Gravemeijer, K., \& Cobb, P. (2006). Design research from a learning design perspective. Educational design research, 17-51.

[12] Gravemeijer, K., \& van Eerde, D. (2009). Design research as a means for building a knowledge base for teachers and teaching in mathematics 
education. The Elementary School Journal, 109(5), 510-524.

[13] Kohar, A.W \& Rosyidi, A.H. (2013) The Development of Mathematics Learning Instruments Integrating Multiple Intelligences on Topics of Cuboid and Cube For The Eighth Grade Students of Junior High School. In: Zulkardi(Eds).The First South East Asia Design/ Development Research (SEADR) International Conference, April 22nd-23rd, 2013, Unsri, Palembang.

[14] Martin, J. D. (2007). Children's understanding of area of rectangular regions and volumes of rectangular shapes and the relationship of these measures to their linear dimensions. Unpublished $\mathrm{PhD}$ thesis. Retrieved from http://hdl. handle. net/10427/53098.

[15] Taylor, A. R., \& Jones, M. G. (2013). Students' and teachers' application of surface area to volume relationships. Research in Science Education, 43(1), 395-411.

[16] Temur, O. D. (2007). The Effects of Teaching Activities Prepared According to the Multiple Intelligence Theory on Mathematics Achievements and Permanence of Information Learned by 4th Grade Students. International Journal of Environmental and Science Education, 2(4), 86-91.

[17] Revina, S., \& van Galen, F. (2011). Spatial Visualization Tasks to Support Students' Spatial Structuring in Learning Volume Measurement. Indonesian Mathematical Society Journal on Mathematics Education, 2(2), 127-146.

[18] Sack, J. J. (2013). Development of a topview numeric coding teaching-learning trajectory within an elementary grades 3D visualization design research project. The Journal of Mathematical Behavior, 32(2), 183-196.

[19] Salmah, U., \& Putri, R. I. I. (2015). TenStructure as Strategy of Addition 1-20 by Involving Spatial Structuring Ability for
First Grade Students. International Education Studies, 8(11), 16.

[20] Suparno, P. (2004). Teori Inteligensi Ganda dan Aplikasinya di Sekolah. Yogyakarta: Kanisius.

[21] Walle, John A. Van De. (2008). Elementary and Middle School Mathematics: Teaching Developementally, 7th edition. Boston: Allyn and Bacon.

[22] Wijaya, A. (2008). Indonesian Traditional Games as Means to Support Second Graders' Learning of Linear Measurement. Mathematics Educations Master Thesis. Utrecht University.

[23] Zulkardi, Z. (2002). Developing a learning environment on realistic mathematics education for Indonesian student teachers (Doctoral dissertation, University of Twente, Enschede). 